\title{
ENTREPRENEURIAL STRATEGIES FOR EMERGING MARKETS
}

\author{
Jamie D. Collins \\ Sam Houston State University $\bullet$ Huntsville, TX \\ Christopher R. Reutzel \\ Sam Houston State University • Huntsville, TX
}

\section{ABSTRACT}

This study involves an investigation into the strategies utilized by entrepreneurial firms in India. Given the number of people living in emerging markets (e.g., China, India, others), understanding which conditions are related to the opportunity-seeking behavior of productive entrepreneurship is an important first step in deriving better policies aimed at improving living standards in countries that have been historically plagued by extreme poverty. Equipped with insights regarding factors that increase opportunity-seeking behavior, scholars, regulators, and practitioners alike can be better positioned to positively shape competitive environments in emerging markets.

\section{INTRODUCTION}

This study involves an investigation into the strategies utilized by entrepreneurial firms in India. Given the number of people living in emerging markets (e.g., China, India, others), understanding which conditions are related to the opportunity-seeking behavior of productive entrepreneurship is an important first step in deriving better policies aimed at improving living standards in countries that have been historically plagued by extreme poverty. Equipped with insights regarding factors that increase opportunity-seeking behavior, scholars, regulators, and practitioners alike can be better positioned to positively shape competitive environments in emerging markets.

Emerging markets represent a unique and complex context in which to examine entrepreneurial activity (Bruton, Ahlstrom \& Obloj, 2008). From a theoretical perspective this is due to the fact that emerging markets are characterized by relatively weak economic institutions (Ahlstrom \& Bruton, 2002). Such 'institutional voids' represent potential barriers to the success of entrepreneurial firms in emerging markets. Entrepreneurial firms competing in emerging markets must pursue strategies that allow them to overcome these challenges. As a result, gaining access to critical and often limited resources represents a fundamental challenge of 
implementing such strategies. From a practical perspective emerging economies are experiencing rapid growth (Hoskisson, Eden, Lau \& Wright, 2000) and increased integration with developed financial markets (Bell, Moore, \& Al-Shammari, 2008), thus also providing significant entrepreneurial opportunities.

With their rapid growth and increasing integration with developed financial markets (Bell, Moore, \& Al-Shammari, 2008), developing economies provide significant entrepreneurial opportunities (North, 2005). Exploitation of these opportunities, however, requires entrepreneurs within these countries to confront institutional challenges frequently not faced by their Western counterparts (Ahlstrom $\&$ Bruton, 2002). For example, the failure to create and protect property rights in developing countries often frustrates entrepreneurs' attempts to appropriate the value they have created, strongly discouraging investment in innovation (Baumol, 2002; Khanna \& Rivken, 2006). Similarly, high transaction costs can delay the introduction and diffusion of innovations by preventing the internalization of technological externalities (Rodrik, 2007) or the incorporation of feedback from the price system (Hayek, 2002; McMullen, Bagby, \& Palich, 2008). Thus, entrepreneurial firms competing in emerging markets must pursue strategies that allow them to overcome these institutional obstacles while simultaneously striving to allocate critical and limited resources as effectively and efficiently as possible.

Firms must respond to idiosyncratic institutional environments to succeed in international markets and develop a competitive advantage. These idiosyncratic constraints directly influence how effectively entrepreneurs choose strategic alternatives and manage key resources under conflicting demands from multiple stakeholders (Delios \& Beamish, 2001; Hitt \& Collins, 2007; Kostova \& Zaheer, 1999).

Understanding variation in firms' strategic choices is a key component of the growing literature that speaks to the effects of managerial decisions on the process of entrepreneurial success. Baumol $(1993 ; 1996)$ argues that entrepreneurs seek profit, not necessarily value-maximizing (from a societal perspective) innovation. As a primarily profit-seeking undertaking, entrepreneurship becomes an activity that can manifest in productive, unproductive, or destructive forms. Productive entrepreneurship "...refers, simply, to any activity that contributes directly or indirectly to net output of the economy or to the capacity to produce additional output" (Baumol, 1993:30). Such opportunity-seeking behavior can be seen in firm actions, such as entering new geographic markets, offering new products or services, re-designing internal processes and/or adopting leading edge technologies. Investing in research and development, market research, or the development of new 
internal capabilities are also activities that indicate that the firm is actively pursuing opportunities for growth and profitability (Baumol, 2002).

Unproductive entrepreneurship consists of rent seeking behaviors (Baumol, 1993, 1996; Dallago, 2000). Rent seeking refers to "any activity whose objective is the acquisition of some of the monopoly profit or the other economic rents currently generated or potentially available in the economy" (Baumol, 2002:61). As such, it represents the "expenditure of resources in (deliberate) pursuit of economic rents by means that do not (automatically) contravene the accepted rules of society" (Baumol, 1993:51). Examples include lobbying, litigation, and takeovers. Thus, attempts to manage relationships with politicians, civil servants, and political consultants, in the effort to change the rules of competition versus comply with the existing rules within one's industry are indicative of rent-seeking (Baumol, 2002).

In spite of the practical and theoretical importance of examining entrepreneurship in emerging markets, few studies have done so. In a recent review of research on entrepreneurship in emerging markets, Bruton and colleagues (2008) found that less than one half of one percent of entrepreneurship articles focused on emerging markets. While a recent special issue in Entrepreneurship Theory and Practice has focused on entrepreneurship in emerging markets there exists a need for much further research in this area. For example, Bruton and colleagues (2008:8) note that the paucity of studies that have examined entrepreneurial activity in India "is not justifiable".

In order to address this gap in extant research we draw upon resource-based logic to argue that the most successful entrepreneurial ventures in India will tend to be those who have an ability to effectively acquire and leverage resources despite the challenges presented by the institutional voids characteristic of the Indian markets. Specifically, we argue that Indian entrepreneurial firms will pursue various options for acquiring resources that can contribute to their performance. These include, but are not limited to, accessing the knowledge and expertise of foreign investors or parent firms as well as leveraging social capital in its various forms. Developing a resource portfolio opens up new strategic options, although the efficient use of resources remains a critical concern to entrepreneurs. 


\section{THEORY DEVELOPMENT}

\section{Institutional Voids}

Prior research has established the fact that the institutional environments differ significantly across countries (Kostova \& Zaheer, 1999, Xu \& Shenkar, 2002). Research also indicates that such differences between countries affect firm-level outcomes, such as the survival of new international subsidiaries (Barkema, Bell \& Pennings, 1996), the inter-unit transfer of processes (Kostova \& Roth, 2002), firms' ability to establish legitimacy in a particular country (Delios \& Beamish, 2001; Kostova \& Zaheer; 1999), and ownership structures in foreign markets. As a result, a firm's performance is shaped by its ability to manage the institutional context of its operations (Hitt et al., 2000, 2004).

Institutional theory suggests that the institutional context is a source of complex sets of information and knowledge with which firms must deal and from which they must learn. Organizations must absorb and utilize the knowledge associated with the multiple institutional constituents (e.g., consumers, regulatory agencies, employees, capital providers, etc.) (DiMaggio \& Powell, 1983; Meyer \& Rowan, 1977). The extent to which firms comprehend the nuances of a particular institutional environment affects their ability to comply with institutional pressures, access resources in the environment and operate successfully in the environment.

Each country has its own unique set of institutions (Kostova, 1999; Kostova \& Zaheer, 1999) that exhibit differing levels of development. The level of institutional development affects the complexity of the knowledge required to operate effectively in a given country and also affects the amount of uncertainty faced by firms competing in these markets (Delios \& Henisz, 2003; Hitt et al., 2004, 2000). For example, greater uncertainty reduces a firm's ability to extract and absorb knowledge from an environment (Cohen \& Levinthal, 1990). Thus, uncertainty reduces the volume of information firms are likely to acquire from any particular market (Podolny, 1994; Tsai, 2001, 2000). The extent to which firms understand a country's institutional environment and develop the necessary resources directly influences the potential for firms to choose effective strategies for operating successfully in that country.

Frequently, emerging markets are economically under-developed due in large part to relatively weak economic institutions (Harriss et al. 1995; Khanna \& Palepu 2000). An important complicating condition facing firms in emerging markets is the existence of "institutional voids" (Khanna \& Palepu 2006, 1997). Such "institutional voids" are barriers to conducting business successfully. Accordingly, companies in 
emerging markets need to utilize their resources to effectively work around existing institutional voids (Khanna et al. 2005; Khanna \& Rivken 2006).

\section{Entrepreneurial Firms' Strategic Responses}

One important factor that may be valuable in overcoming the challenges presented by the institutional voids typical of emerging markets is the presence or absence of a foreign parent to entrepreneurial ventures in emerging markets. Entrepreneurial firms can find themselves at a competitive disadvantage to foreign competitors. This liability of localness (Perez-Batres, 2012; Perez-Batres \& Eden, 2008 ) is expected to be particularly profound for entrepreneurial firms. Foreign investors in emerging market entrepreneurial firms typically come from home countries with stronger economic institutions. The experience and knowledge of doing business in a more stable institutional environment may provide them with advanced expertise in legal agreements and deal structuring to protect their property rights within investment deals in emerging markets. It also suggests that they may possess skills in identifying attractive economic opportunities in emerging markets. As a result, it is reasonable to expect to find a positive relationship between foreign ownership and the performance of entrepreneurial firms in emerging markets.

\section{Hypothesis 1: Entrepreneurial firms perform better in emerging markets if the firm has a foreign parent.}

The upper echelons literature emphasizes the importance of key leaders and their social capital to the performance of their respective firms. Social capital facilitates access to a range of resources and knowledge needed in order to thrive in competitive markets (Kostova \& Roth, 2002). Yet, while the nature of social capital ties is that they facilitate exchange and discourage opportunism among partners, developing and maintaining social ties can also be quite costly. Entrepreneurs maintaining numerous social ties are likely constrained in executing their responsibilities to their firms because these ties require ongoing resources and attention to maintain. Additionally, the more ties an entrepreneur maintains, the less time, energy and attention can be devoted to innovation and creativity within her/ his firm. Thus, entrepreneurs holding multiple external ties may be less effective in making resource-allocation decisions than entrepreneurs with a limited number of ties. This suggests that the added value of additional social capital decreases while the costs to develop this capital remains high Thus, we expect to find a curvilinear 
relationship between the number of social capital ties held by entrepreneurial firms' key executives and the performance of their firms.

\section{Hypothesis 2: The performance of entrepreneurial firms in emerging markets is curvilinearly related (inverted $U$-shape) to the number of social capital ties held by the firm's leaders.}

According to Baumol, entrepreneurs will pursue whichever form of behavior promises the most expected payout (Baumol, 1993, 1996). Which form of entrepreneurial behavior manifests within a nation's economy (and to what extent) is then explained in terms of the politico-economic institutional conditions in which this behavior occurs (Baumol, 2002; North, 1990). The existence of productive entrepreneurship depends on the incentives provided by institutions (Baumol, 2002). North (2005:2) suggests that people construct elaborate beliefs about the reality of the politico-economic system which serve as "both a positive model of the way the system works and a normative model of how it should work" and adds that, over time, these beliefs result in "the accretion of an elaborate structure of institutions that determine economic and political performance."

Firms have a range of competitive options available to them including the adoption of an entrepreneurial posture (Kuratko, Hornsby, \& Goldsby, 2007). Managers are constantly seeking new ways of improving their capabilities, processes, and product offerings to enrich the value proposition offered to customers (Kuratko, Ireland, Covin, \& Hornsby, 2005).

Entrepreneurship involves innovations that are expected to develop to be consequential innovations that and adopted in support of/aid in the firm's pursuit for competitive advantage (Morris, Kuratko, \& Covin, 2008). These innovations can focus on the firm's strategy, product offerings, internal organization, market focus, or business model (Ireland \& Webb, 2007). Furthermore, having this type of intentional reliance on entrepreneurial behavior can rejuvenate the organization through recognition and exploitation of entrepreneurial opportunities (Ireland et al., 2009). Thus, innovation is an essential component of successful corporate entrepreneurship (Ireland, Kuratko, \& Morris, 2006a, b). Commonly, innovation is considered to be product or process improvements that result in increased value for the firm's customers thereby helping the firm to achieve or maintain a competitive advantage (Kuratko et al., 2005). However, firms can innovate in a variety of ways ranging from relatively minor (yet valuable to the customer) changes to existing products, processes, or services to radically new products, services or processes. 
Minor changes can include improvements in: reliability, size, performance or specific product features. Radical breakthroughs in products, processes or services can introduce unique and attractive features, substantial cost improvements and/or exceptional performance. Thus, innovation can involve a relatively small number of discrete changes as well as numerous continuous improvements by the firm. Regardless of the frequency and size of innovative actions, corporations can benefit from having their internal processes organized to support incremental adaptation and major changes (Kuratko, Hornsby, \& Corso, 1996).

To enact innovation requires firms to develop and use new ideas in ways that create value (Linder, Jarenpaa, \& Davenport, 2003). Innovation can become a primary vehicle to improved productivity and greater profitability in highly dynamic environments. By having an intentional focus on how to best deliver value to consumers, firms that embrace innovation can often create sustainable growth (McEvily, Eisenhardt, \& Prescott, 2004). Firms can foster innovation by promoting the development and adoption of new products, services or processes that increase profitability and overall competitiveness (Zahra, Nielsen, \& Bogner, 1999). Companies can leverage their innovative capabilities by engaging in strategic entrepreneurship, which involves simultaneous opportunity-seeking and advantage-seeking behaviors and may result in superior performance (Ireland, Hitt, \& Sirmon, 2003).

Firms rely on well-developed internal capabilities and knowledge in order to achieve desired levels of performance. Acquisitions are expected to be associated with better performance because, a) they provide access to resources that are particularly hard to find in factor markets, and b) only firms that have well-developed internal capabilities are likely to be able to execute acquisitions in emerging economies. The expertise required to complete acquisitions is also expected to be beneficial in terms of making decisions regarding offering new products or services, entering new geographic markets, and improving processes or technologies. Entrepreneurial firms' performance in emerging markets should therefore be positively associated with recent acquisition activity.

\section{Hypothesis 3: The performance of entrepreneurial firms in emerging markets is positively related to the number of recent acquisitions that firm has completed.}

The scope of products/services offered represents an additional aspect of firm strategy that may influence the performance of entrepreneurial firms in emerging 
markets. Others have argued that institutional voids in emerging markets often make a highly diversified competitive position desirable for achieving greater firm performance (Khanna \& Palepu, 1997, 2006; Khanna et al., 2005). Given the resource constraints typical of entrepreneurial ventures, combined with the necessary allocation of resources required to cope with the institutional voids in emerging markets, an alternative perspective is that entrepreneurial firms will lack sufficient resources to successfully manage a broad product/service lines. Conversely, entrepreneurial firms in emerging markets that pursue a more focused approach will more likely possess sufficient resources to implement effective strategies to market their product/service lines. Formally stated, we hypothesize the following:

\section{Hypothesis 4: Entrepreneurial firms' performance in emerging markets is negatively related to the number of products/services offered.}

\section{METHODS}

This study involves survey responses from 170 founders and senior executives of entrepreneurial firms in India. Due to the importance placed on inter-personal relationships for entrepreneurs and in emerging markets, we used in-person, semistructured interviews in this study. This approach helped improve response rates and data quality. The survey instrument was written in English and was pre-tested in India and the U.S. English is one of the official languages of India, is typically the language of choice for business and is also the language in which almost all business contracts are written. The pretests involved a total of 12 senior executives from Indian firms. Face validity and content validity of the instrument and its items were assessed by multiple researchers with experience in conducting survey research via the pretests of the survey. Input regarding the instrument was also solicited from 3 business professors and 4 graduate students in India. In the U.S., feedback was gathered from a total of 5 business professors (including 2 from India), 2 Indian doctoral students in business and 2 business people of Indian heritage.

We measured firm performance by using a multi-item perceptual measure appropriate to assess firm performance in an emerging economy (Tan \& Litschert, 1994). See Table 4 for a listing of individual items and their factor loadings. The 'performance' measure assesses the firm's relative position vis-à-vis its competitors in the areas of: assets, return on sales, sales growth, profitability and overall competitive position. The reliability of this measure was $\alpha=.944$. 


\section{CONTROL VARIABLES}

Several variables were controlled for to eliminate alternative explanations to the hypotheses. These include: industry, firm age (in years since founding), and size (represented by the natural log of the number of the firm's full-time employees) (Collins et al., 2009; Uhlenbruck et al., 2006). Older and/or larger firms might have greater access to economic or political opportunities and less motivation to engage in innovative behavior as a result of having acquired many of the resources needed to be competitive or having established influential relationships with relevant constituents in the past. In addition, older firms are thought to have less concern for survivability than younger firms (Stinchcombe, 1965). Firm age (in years since founding) and size (represented by the logarithm of the number of the firm's fulltime employees), diversification, primary industry membership, industry structure, and market volatility were included as control variables. We also controlled for the percentage of each firm's revenues attributable to the government as customer. Further, a measure was included in the survey specifically to measure whether interviewees were likely providing socially-desirable responses. This approach is consistent with prior research (Collins, et al., 2009). The items were obtained from the Balanced Inventory of Desirable Responding (Paulhus, 1991).

Given that pressures to adapt the environmental constraints vary by industry, we controlled for industry differences (e.g., Brown, Davidsson \& Wiklund, 2001; Collins et al., 2009) by categorizing all industries represented in the survey as either: Basic Sector, Manufacturing, Wholesale and Retail, Professional Industries, or Other. The 'Professional Industries' category is comprised of firms engaged in financial, legal, business consulting, accounting, and health services. Firms providing these services rely on highly trained employees and top managers who demonstrate very strong loyalty to their profession (Løwendahl, 2000). The 'Basic Sector' category consists of firms whose primary business activities are related to agriculture (livestock production, fishing, and forestry), construction, mining, and quarrying. The 'Manufacturing' category represents all firms engaged in production of consumer and/or industrial products. The 'Wholesale and Retail' category encompasses such activities as retail shops and stores, tourism, hotels, restaurants, storage, transportation, and all non-professional service activities. All firms which fell outside of these four categories are grouped into 'Other'.

Foreign ownership is a dichotomous variable indicating whether or not the firm has at least one foreign parent. Entrepreneur's social capital is a multi-item measure which assesses the number of connections the participating executives 
have to various other family businesses, bank ownership interests, and connections to civil servants and politicians. The recent acquisitions variable is a count of the number of acquisitions the firm has completed within the past three years. Finally, we also included a count measure related to the number of Products or Services currently being produced by the firm.

Due to the importance placed on inter-personal relationships for entrepreneurs (Coviello \& Jones, 2004) in emerging markets (Hitt, et al., 2002), we used in-person, structured interviews conducted by interviewers who each have some social or business network connection with the respondents. This approach helps improve response rates and data quality, as well as mitigate the risk of socially-desirable responses (Kirkman \& Law, 2005). Study respondents were specifically assured that all responses would be kept confidential. Responses to sensitive questions were worded such that they did not implicate the respondent of potentially embarrassing behavior. Sensitive questions were asked toward the end of the interview, after the interviewer had time to establish credibility and trust; these questions were asked in different sections of the instrument.

\section{$\overline{\text { RESULTS }}$}

Table 1 presents the results of our statistical analyses. Table 2 summaries these results. Each of our four hypotheses received support in our analytical models. Hypothesis 1 was supported at the .05 level of significance. Entrepreneurial firms in India saw performance benefits from having at least one parent being a foreign firm. Hypothesis 2 was supported at the .01 level; i.e., a curvilinear relationship was found between entrepreneurial firms' use of key executives' social capital and their firms' performance. Hypothesis 3 was supported at the .05 level of significance. Thus, a positive relationship was found between the number of recent acquisitions made by entrepreneurial firms and their performance. Conversely, a negative relationship was found for the level of diversification (number of products / services) and entrepreneurial firms' performance in India. This provided support for Hypothesis 4 , at the .05 level of significance. The adjusted R2 and F values in Table 1 also demonstrate support for each of our models. The Adjusted R2 value increases from .125 in Model 1 to .261 in Model 2. Moreover, Model 1 is statistically significant at the .01 level, whereas Model 2 is significant at the .001 level. These results collectively demonstrate that the inclusion of each set of independent variables in Model 2 contributes significant additional explanatory power to the model. 
These models therefore provide evidence that the performance of entrepreneurial firms in India is influenced by the strategic choices made by those firms.

\section{$\overline{\text { SIGNIFICANCE OF STUDY }}$}

Findings provide empirical support for Baumol's (2002) contention that entrepreneurs will respond predictably to the incentives provided by such institutions and that these institutions are largely responsible for channeling entrepreneurial talent towards or away from productive entrepreneurship (Baumol, Litan, and Schramm, 2007a, 2007b).

We chose to sample from Indian entrepreneurs because India offered a political economy whose institutions possessed the rules-based institutions of capitalism, such as rule of law, property rights, and markets (Zacharakis et al., 2007). But it also possessed many of the marks of a relationship-based economy, which are often susceptible to corruption when transitioning from personal exchange to arm's length market transactions (Zacharakis et al., 2007). Such institutional conditions help to ensure that all three forms of entrepreneurial behavior are plausible options for even the most legitimate of entrepreneurial ventures. However, developing economies often tend to have a large informal economy as well, which we did not study. Thus, the unique configuration of rules-based and relationship-based institutional characteristics combined with our sample of legally registered ventures suggests that our findings may be specific to entrepreneurs operating in the formal sector of emerging economies. With India boasting over one-fifth of the world's population and one of the planet's largest and fastest growing economies, however, such generalizability concerns are greatly assuaged.

This study examines performance of entrepreneurial ventures in a unique context, the emerging market of India. In doing so, this study contributes to a growing body of research on entrepreneurship in international settings. Additionally, this study provides insight into the role of resource management in entrepreneurial firms in overcoming institutional voids. In particular this study finds support for the idea that entrepreneurs use a variety of methods for maximizing their profit potential. Although institutional voids in emerging markets pose challenges for innovation, entrepreneurial firms with a foreign parent rely on resource access provided by such a parent to overcome resource challenges. They also rely on social capital connections to enable them to capture entrepreneurial opportunities. Results also show that entrepreneurial firms in India utilize acquisitions as a profitable 
avenue for firm growth. However entrepreneurial firms in India relied on product/ service diversification for firm growth, evidence suggests the performance of these firms suffer.

\section{REFERENCES}

Alstrom, D. and Bruton, G. D, (2002), "An institutional perspective on the role of culture in shaping strategic actions by technology focused entrepreneurial firms in China", Entrepreneurship Theory and Practice, 26(4), 53-70.

Baumol, W.J. (1993), Entrepreneurship, management, and the structure of Payoffs. Cambridge, MA: The MIT Press.

Baumol, W.J. (1996), "Entrepreneurship: Productive, unproductive, and destructive”, Journal of Business Venturing, 11(1), 3-22.

Baumol, W.J. (2002), The Free-Market Innovation Machine: Analyzing the Growth Miracle of Capitalism. Princeton, NJ: Princeton University Press.

Baumol, W.J., Litan, R.E., \& Schramm, C.J. (2007a), Good capitalism, bad capitalism, and the economics of growth and prosperity. New Haven, CT: Yale University Press.

Baumol, W.J., Litan, R.E., \& Schramm, C.J. (2007b), Sustaining entrepreneurial capitalism. Capitalism and Society, 2(2), 1-36.

Bell, R. G., Moore, C. B. \& Al-Shammari, H. A. (2008), "Country of origin and foreign IPO legitimacy: Understanding the role of geographic scope and insider ownership", Entrepreneurship Theory and Practice. 32(1), 185-202.

Brown, T.E., Davidsson, P. \& Wiklund, J. (2001), "An operationalization of Stevenson's conceptualization of entrepreneurship as opportunity-based firm behavior", Strategic Management Journal, 22(10), 953-968.

Bruton, G. D., Ahlstrom, D., and Obloj, K. (2008), "Entrepreneurship in emerging economies: Where are we today and where should the research go in the future", Entrepreneurship Theory and Practice. 32(1), 1-14

Cohen, W. M. and Levinthal, D. A. (1990), “Absorptive capacity: A new perspective on learning and innovation", Administrative Science Quarterly, 35, 128-52.

Collins, J. D., Uhlenbruck, K. \& Rodriguez, P. (2009), "Why firms engage in corruption: A top management perspective", Journal of Business Ethics, 87(1), 89-108.

Coviello, N. E. \& Jones, M. V. (2004), "Methodological issues in international entrepreneurship research", Journal of Business Venturing, 19(4), 485-508. 
Dallago, B. (2000), "The organizational and productive impact on the economic system: The case of SMEs", Small Business Economics, 15,303-319.

Delios, A. \& Beamish, P. (2001), "Survival and profitability: The roles of experience and intangible assets in foreign subsidiary performance", Academy of Management Journal, 44, 1028-1038.

Delios, A. and Henisz, W. J. (2003), "Political hazards, experience and sequential entry strategies: The international expansion of Japanese firms, 1980-1998", Strategic Management Journal, 24, 1153-1164.

DiMaggio, P.J. and Powell, W.W. (1983), "The iron cage revisited: Institutional isomorphism and collective rationality in organizational fields", American Sociological Review, 48, 147-160.

Harriss, J., Hunter, J., \& Lewis, C. J. (1995), The New Institutional Economics and Third World Development, Routledge, London, UK.

Hayek, F.A. (2002), “Competition as a discovery procedure", Quarterly Journal of Austrian Economics, 5(3), 9-23.

Hitt, M.A., \& Collins, J.D. (2007), "Business ethics, strategic decision making and firm performance", Business Horizons, 50(5), 353-357.

Hitt, M. A., Dacin, M. T., Levitas, E., Arregle, J.-L. and Borza, A. (2000), "Partner selection in emerging and developed market contexts: Resource-based and organizational learning perspectives", Academy of Management Journal, 43, 449-467.

Hitt, M.A., Ahlstrom, D., Dacin, M.T., Levitas, E. and Svobodina, L. (2004), "The institutional effects on strategic alliance partner selection in transition economies: China versus Russia", Organization Science, 15, 173-185.

Hoskisson, R. E., Eden, L., Lau, C. M., and Wright, M. (2000), "Strategy in Emerging Economies", Academy of Management Journal, 43, 249-267.

Ireland, R. D., Covin, J. G., \& Kuratko, D. F. (2009), "Conceptualizing corporate entrepreneurship strategy", Entrepreneurship Theory and Practice, 33(1), 1946.

Ireland, R. D., Hitt, M. A., \& Sirmon, D. G. (2003), "A model of strategic entrepreneurship: The construct and its dimensions", Journal of Management, 29(6), 963-989.

Ireland, R. D., Kuratko, D. F., \& Morris, M. H. (2006a), "A health audit for corporate entrepreneurship: innovation at all levels: part I", The Journal of Business Strategy, 27(1), 10. 
Ireland, R. D., Kuratko, D. F., \& Morris, M. H. (2006b), “A health audit for corporate entrepreneurship: innovation at all levels: part II", The Journal of Business Strategy, 27(2), 21.

Ireland, R. D., \& Webb, J. W. (2007), "A Cross-Disciplinary Exploration of Entrepreneurship Research", Journal of Management, 33(6), 891-927.

Khanna, T., \& Palepu, K. (1997), "Why Focused Strategies may be Wrong for Emerging Markets:, Harvard Business Review, 75(4), 41-51.

Khanna, T. \& Palepu, K. (2000), "Is Group Affiliation Profitable in Emerging Markets? An Analysis of Diversified Indian Business Groups", Journal of Finance, 55(2), 867-891.

Khanna, T. \& Palepu, K. (2006), "Emerging Giants". Harvard Business Review, 84(10), 60-69.

Khanna, T. \& Rivkin, J.W. (2006), "Interorganizational Ties and Business Group Boundaries: Evidence From an Emerging Economy”, Organization Science, 17(3), 333-352.

Khanna, T., Palepu, K., \& Sinha, J. (2005), “Strategies That Fit Emerging Markets", Harvard Business Review, 83(60), 63-76.

Kirkman, B. \& Law, K. (2005), "International management research in AMJ: Our past, present, and future", Academy of Management Journal, 48(3), 377-386.

Kostova, T. (1999), "Transnational transfer of strategic organizational practices: A contextual perspective, Academy of Management Review, 24, 308-324.

Kostova, T. \& Roth, K. (2002), "Adoption of an organizational practice by subsidiaries of multinational corporations: Institutional and relational effects", Academy of Management Journal, 45, 215-233.

Kostova, T. \& Zaheer, S. (1999), “Organizational legitimacy under conditions of complexity: the case of the multi-national enterprise", Academy of Management Review, 24, 64-81.

Kuratko, D. F., Hornsby, J. S., \& Goldsby, M. G. (2007), “The Relationship of Stakeholder Salience, Organizational Posture, and Entrepreneurial Intensity to Corporate Entrepreneurship", Journal of Leadership \& Organizational Studies, $13(4), 56$.

Kuratko, D. F., Ireland, R. D., Covin, J. G., \& Hornsby, J. S. (2005), “A Model of Middle-Level Managers' Entrepreneurial Behavior", Entrepreneurship Theory and Practice, 29(6), 699.

Løwendahl, B. (2000), Strategic management of professional service firms (2nd ed.), Copenhagen, Denmark: Copenhagen Business School Press. 
McMullen, J.S., Bagby, R., \& Palich, L. (2008), "Economic freedom and the motivation to engage in entrepreneurial action", Entrepreneurship: Theory \& Practice, 32(5), 875-895.

Meyer, J. \& Rowan, B. (1977), "Institutionalized organizations: Formal structure as myth and ceremony", American Journal of Sociology, 83, 340-363.

North, D. (2005), Understanding the process of economic change. Princeton: Princeton University Press.

Paulhus, D. L. (1991), Measurement and control of response bias. In J. Robinson, P. Shaver \& L. Wrightsman (Eds.), Measures of personality and social psychological attitudes. San Diego, CA: Academic Press.

Perez-Batres, L. A. (2012), "Efficient labor reallocation and the liability of localness: Unintended consequences of NAFTA and other commercial agreements", American Journal of Business. 27(1), 79-90.

Perez-Batres, L.A. \& Eden, L. (2008), "Is there a liability of localness? How emerging market firms respond to regulatory punctuations", Journal of International Management. 14(3), 232-251.

Podolny, J. M. (1994), "Market uncertainty and the social character of economic exchange", Administrative Science Quarterly, 39, 458-483.

Rodrik, D. (2007), One economics many recipes: Globalization, institutions, and economic growth. Princeton, NJ: Princeton University Press.

Stinchcombe, A. (1965), "Social structures and organizations", In J.G. March (Ed.), Handbook of Organizations: 153-193. Chicago: Rand McNally.

Tan, J.J. \& Litschert, R.J. (1994), "Environment-strategy relationship and its performance implications: an empirical analysis of the Chinese electronics industry", Strategic Management Journal, 15(1), 1-20.

Tsai, W. (2000), "Social capital, strategic relatedness and the formation of intraorganizational linkages", Strategic Management Journal, 21, 925-939.

Tsai, W. (2001), "Knowledge transfer in intraorganizational networks: Effects of network position and absorptive capacity on business unit innovation and performance", Academy of Management Journal, 44, 996-1004.

Uhlenbruck, K., Rodriguez, P., Doh, J., \& Eden, L. (2006), “The impact of corruption on entry strategy: Evidence from telecommunication projects in emerging economies", Organization Science, 17, 402-414.

Zacharakis, A.L., McMullen, J.S., \& Shepherd, D.A. (2007), "Venture capitalists' decision policies across three countries: An institutional theory perspective", Journal of International Business Studies, 38, 691-708. 


\section{BIOGRAPHICAL SKETCH OF AUTHORS}

Jamie D. Collins received his Ph.D. from Texas A\&M University, specializing in Strategic Management and Entrepreneurship; he is currently an Associate Professor at Sam Houston State University. He teaches courses in Strategic Management, Entrepreneurship / Family Business and Corporate Social Responsibility. He has previously served as a founding member of a private equity group, where he led investment screening and due diligence for the firm. Other prior industry experience includes: aerospace/defense, energy, financial services, software, real estate, and agri-business.

Christopher R. Reutzel, $\mathrm{PhD}$ is an Assistant Professor at Sam Houston State University. He has a doctorate in Strategic Management from Texas A\&M University. His research interests include Strategic Leadership, Entrepreneurship, and Emerging Markets. 
Table 1

Regression Models

\begin{tabular}{|l|l|l|}
\hline \multicolumn{1}{|c|}{ Dependent Variable $=$ Firm Performance } & \multicolumn{1}{|c|}{ Model 1 } & \multicolumn{1}{|c|}{ Model 2 } \\
\hline Control Variables & & \\
\hline Firm Age & 0.004 & -0.001 \\
\hline Firm Size & $1.223^{\star \star}$ & $1.236^{\star \star}$ \\
\hline Diversification & -0.136 & -0.066 \\
\hline Socially Desirable Response Index & 0.036 & $0.071 \dagger$ \\
\hline Basic Sector Industry & -0.074 & 0.082 \\
\hline Wholesale \& Retail Industry & 0.087 & 0.071 \\
\hline Professional Services Industry & $0.490 \dagger$ & 0.333 \\
\hline Other Industries & 0.200 & 0.259 \\
\hline Sales \% to Govt. & 0.004 & 0.001 \\
\hline Industry Structure & $0.115^{\star}$ & $0.087 \dagger$ \\
\hline Market Volatility & 0.019 & 0.024 \\
\hline Independent Variables & & \\
\hline Foreign Parent & & $1.018^{\star}$ \\
\hline Entrepreneur's Social Capital & & $-0.294^{\star \star}$ \\
\hline Entrepreneur's Social Capital 2 & & $0.015^{\star \star}$ \\
\hline Number of Recent Acquisitions & & $0.204^{\star}$ \\
\hline Number of Products/Services & & -0.001 \\
\hline Adjusted R2 & & $3.758^{\star \star *}$ \\
\hline F value & & \\
\hline Notes: No170; & & \\
\hline
\end{tabular}

Notes: $\mathrm{N}=170 ; \dagger \mathrm{p}<.10 ; * \mathrm{p}<.05 ; * * \mathrm{p}<.01 ; * * * \mathrm{p}<.001$ 
Table 2

Summary of Results

Hypothesis 1: Positive relationship between firm performance and having a foreign parent

- Supported (.05)

Hypothesis 2: Curvilinear relationship between executive social capital and firm performance

- Supported (.01)

Hypothesis 3: Positive relationship between firm performance and number of recent acquisitions

- Supported (.05)

Hypothesis 4: Negative relationship between firm performance and number of products/ services offered

- Supported (.05) 


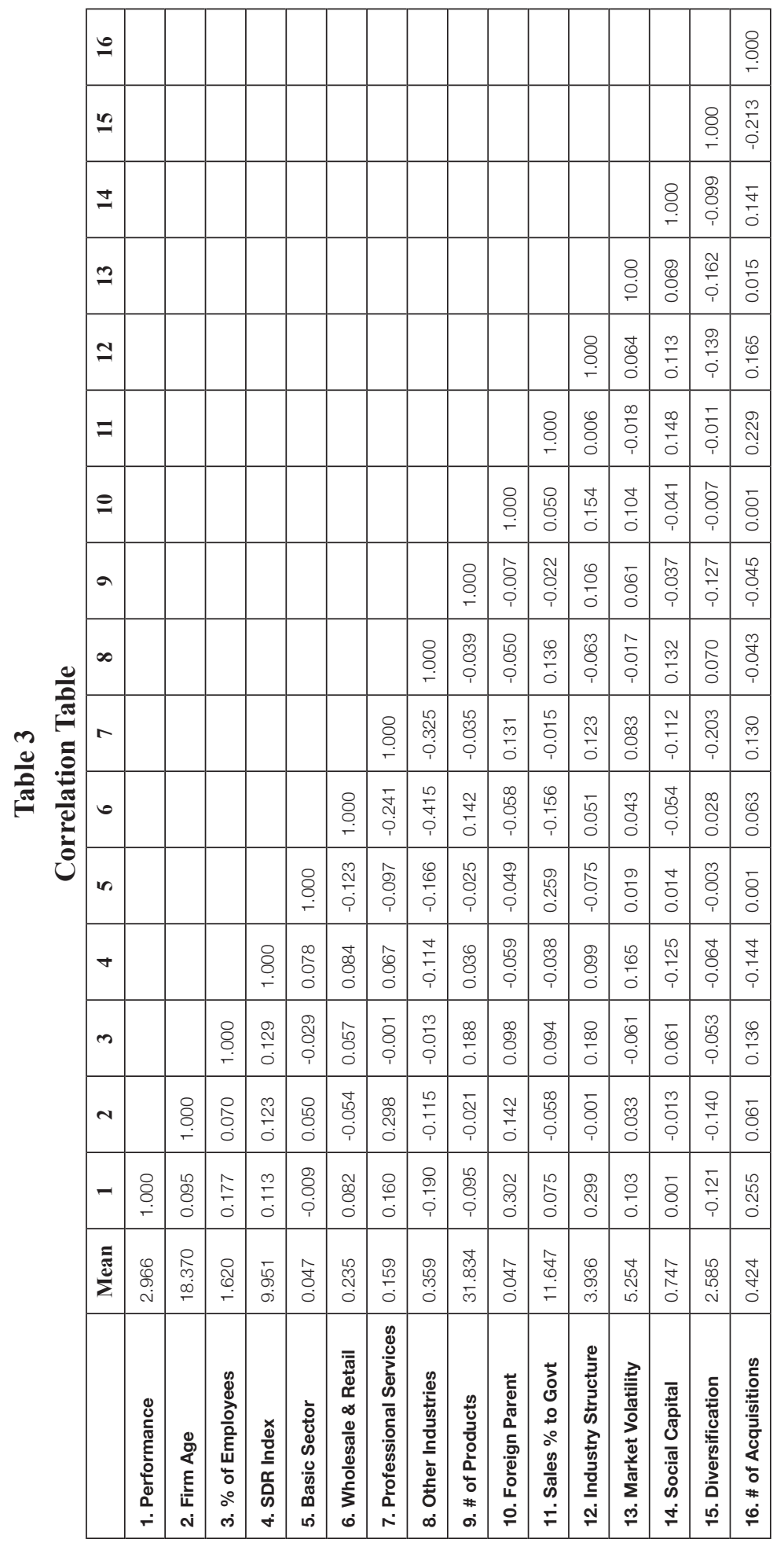


Table 4

\begin{tabular}{|l|l|}
\hline \multicolumn{1}{|c|}{ Performance } & \multicolumn{1}{|c|}{$\begin{array}{c}\text { Factor } \\
\text { Loadings }\end{array}$} \\
\hline 1. Size of total asset base as compared to your competitors & 0.826 \\
\hline 2. After-tax return on total sales as compared to your competitors & 0.821 \\
\hline 3. Firm total sales growth compared to your competitors & 0.839 \\
\hline 4. Overall firm performance and success compared to your competitors & 0.870 \\
\hline 5. Firm competitive position compared to your competitors & 0.845 \\
\hline
\end{tabular}

